\title{
Overview of the anti-inflammatory effects, pharmacokinetic properties and clinical efficacies of arctigenin and arctiin from Arctium lappa $L$
}

\author{
Qiong GAO, Mengbi YANG, Zhong ZUO* \\ School of Pharmacy, Faculty of Medicine, The Chinese University of Hong Kong, Hong Kong SAR, China
}

\begin{abstract}
Arctigenin (AR) and its glycoside, arctiin, are two major active ingredients of Arctium lappa L (A lappa), a popular medicinal herb and health supplement frequently used in Asia. In the past several decades, bioactive components from $A$ lappa have attracted the attention of researchers due to their promising therapeutic effects. In the current article, we aimed to provide an overview of the pharmacology of AR and arctiin, focusing on their anti-inflammatory effects, pharmacokinetics properties and clinical efficacies. Compared to acrtiin, AR was reported as the most potent bioactive component of $A$ lappa in the majority of studies. AR exhibits potent anti-inflammatory activities by inhibiting inducible nitric oxide synthase (iNOS) via modulation of several cytokines. Due to its potent anti-inflammatory effects, AR may serve as a potential therapeutic compound against both acute inflammation and various chronic diseases. However, pharmacokinetic studies demonstrated the extensive glucuronidation and hydrolysis of AR in liver, intestine and plasma, which might hinder its in vivo and clinical efficacy after oral administration. Based on the reviewed pharmacological and pharmacokinetic characteristics of AR, further pharmacokinetic and pharmacodynamic studies of AR via alternative administration routes are suggested to promote its ability to serve as a therapeutic agent as well as an ideal bioactive marker for $A$ lappa.
\end{abstract}

Keywords: arctigenin; arctiin; Arctium lappa L; Fructus Arctii; anti-inflammatory agents; pharmacokinetics; clinical efficacy

Acta Pharmacologica Sinica advance (2018) 39: 787-801; doi: 10.1038/aps.2018.32; published online 26 Apr 2018

\section{Introduction}

Arctigenin (AR) (Figure 1), a phenylpropanoid dizbenzylbutyrolactone lignan, was first identified in Arctium lappa L (A lappa), a popular medicinal herb and health supplement frequently used for anti-influenza treatment in Asia, especially China, Korea and Japan. AR and its glycoside, arctiin, are listed as both the chemical marker compounds and major active ingredients of Fructus Arctii in Chinese Pharmacopeia ${ }^{[1]}$. In the past several decades, bioactive components from $A$ lappa, especially $\mathrm{AR}$, have attracted the attention of researchers due to their promising therapeutic effects on inflammation ${ }^{[2-4]}$, infection $^{[5-7]}$, metabolic disorders ${ }^{[8-10]}$, and central nervous system dysfunctions ${ }^{[11-13]}$.

AR and arctiin have been extensively studied for their anti-inflammatory effects in both in vitro and in vivo models. Inflammation is a series of protective responses of the body against exogenous pathogens and to repair tissue damage

\footnotetext{
* To whom correspondence should be addressed.

E-mail joanzuo@cuhk.edu.hk

Received 2017-10-30 Accepted 2018-01-07
}

resulting from infection or trauma. Acute inflammation is characterized by vasodilatation, fluid exudation and neutrophil infiltration ${ }^{[14]}$. Severe inflammation can cause organ injury, shock and even death, presenting major management problems ${ }^{[14]}$. Furthermore, when the inflammatory response does not eradicate the primary stimulus, a chronic form of inflammation ensues and contributes to further tissue damage. A number of chronic diseases, including atherosclerosis, cancer, type II diabetes, and Alzheimer's disease, have a pathophysiologically important inflammatory component ${ }^{[15]}$. Therefore, developing novel compounds targeting the inflammatory response can be beneficial for the treatment of acute inflammation and infection, as well as many widespread chronic diseases. Studies on the pharmacology of AR and arctiin as natural compounds with significant anti-inflammatory effects may contribute to the development of novel anti-inflammatory therapeutics.

Pharmacokinetic profiles, including the absorption, distribution, metabolism and excretion properties, determine the efficacy and safety of a potential therapeutic. Extensive in vitro and in vivo studies have been conducted on AR and arctiin 


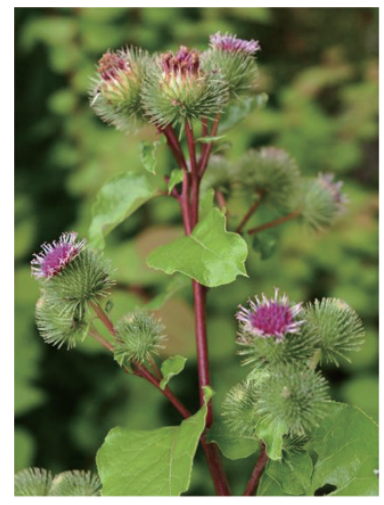

A

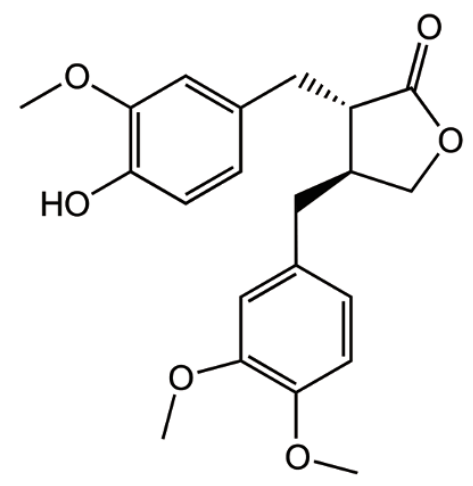

D

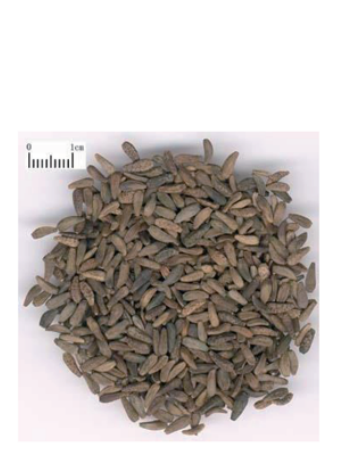

B

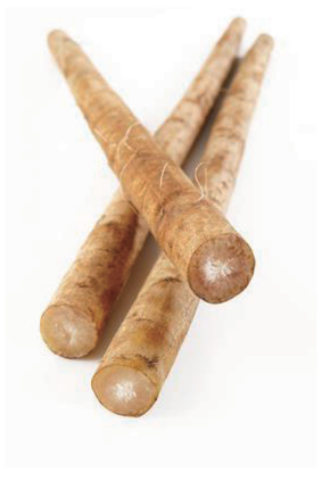

C<smiles>COc1ccc(C[C@@H]2COC(=O)[C@@H]2Cc2ccc(O[C@@H]3O[C@H](CO)[C@@H](O)[C@H](O)[C@H]3O)c(OC)c2)cc1OC</smiles>

E

Figure 1. Arctium lappa L: plant (A), fruit (Fructus Arctii) (B), root (C), and two major bioactive compounds, AR (D) and arctiin (E).

to elucidate their absorption, metabolite profiles, and plasma concentration profiles, as well as the mechanisms involved. The results of these studies provide comprehensive data on the pharmacokinetic properties of AR and arctiin, leading to further optimization strategies for the use of these natural compounds as potential anti-inflammatory therapeutics.

Although research interest in AR, arctiin and A lappa has been growing rapidly, there are few published review articles on their pharmacological characteristics. In the current article, we aim to provide an overview of the pharmacology of AR and arctiin, especially their anti-inflammatory effects, pharmacokinetics properties and clinical efficacy.

\section{Distribution of AR and arctiin in plants}

$\mathrm{AR}$ and arctiin belong to the family of lignans, which is a class of phytoestrogens characterized by their dibenzylbutane skeleton. Lignans were first identified in plants and are believed to play a role in the construction of plant cell wall as the precursor of lignin. The contents of AR and arctiin, as well as the total lignans, were found to be the highest in the fruit of A lappa among all the plant parts ${ }^{[16]}$. AR and arctiin account for approximately $0.5 \%-2 \%(w / w)$ and $2 \%-10 \%(w / w)$ of the dry weight of the fruit, respectively, depending on place of origin, processing methods, and other factors ${ }^{[17,18]}$. AR is regarded as marker compound in dozens of other medicinal herbs, probably due to its promising therapeutic activities ${ }^{[19,20]}$. AR and arctiin have been identified in not only A lappa but also more than 38 other plant species, among which $71 \%$ belong to the Asteraceae family. Table 1 summarizes the distribution of AR and arctiin in different plant species from eight families, including Aspleniaceae, Asteraceae, Convolvulaceae, Linaceae, Oleaceae, Styracaceae, Taxacea, and Thymelaeaceae. In the family Asteraceae, Centaurea is a genus that includes many AR- and arctiin-containing plants, although the AR and arctiin contents are lower than that in A lappa. Fruits and seeds had high levels of AR and arc$\operatorname{tiin}^{[2,21]}$, while the other parts, such as flower, leaves, stem, and roots, had low levels (Table 1). As shown in Table 1, many of these AR- and arctiin-containing plants are recorded as medical plants in their growing areas and are well-recognized for the treatment of diseases, such as rheumatic arthritis, inflammatory diseases, infection, and others.

\section{Effect of AR and arctiin against inflammatory diseases} Effect of $A R$ and arctiin on acute inflammation and its mechanism Multiple studies have found that A lappa exhibits antiinflammatory activities, which were attributed to AR in most research focusing on the traditional Chinese herb ${ }^{[22-24]}$. The anti-inflammatory effect and the reported mechanism of AR are summarized in Table 2.

The anti-inflammatory effects of AR were demonstrated in 
Table 1. Plants species containing AR or arctiin and their medical usages.

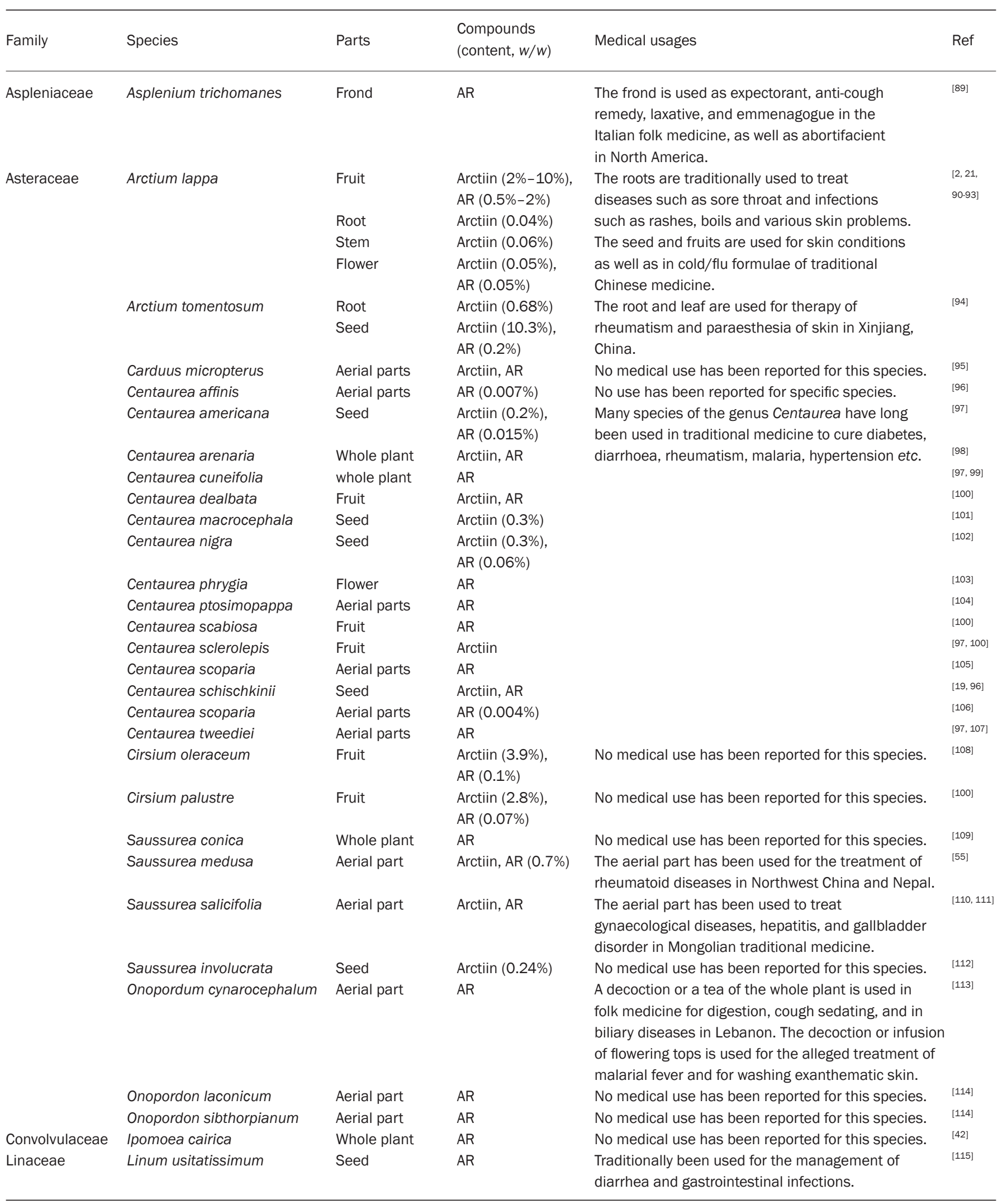




\begin{tabular}{|c|c|c|c|c|c|}
\hline Family & Species & Parts & $\begin{array}{l}\text { Compounds } \\
\text { (content, } w / w)\end{array}$ & Medical usages & Ref \\
\hline \multirow[t]{5}{*}{ Oleaceae } & Forsythia intermedia & Flower, leave & Arctiin & No medical use has been reported for this species. & [116] \\
\hline & Forsythia koreana & Fruit & Arctiin, AR & $\begin{array}{l}\text { Forsythia fruits from the three species are known } \\
\text { in China, Korea, and Japan as an anti-inflammatory, } \\
\text { diuretics, antidote, and anti-bacteria medicine in } \\
\text { traditional herbal medicine. }\end{array}$ & {$[25,33]$} \\
\hline & Forsythia suspense & Fruit & AR (0.36\%) & & [25] \\
\hline & Forsythia viridissima & Fruit, flower & Arctiin, AR & & {$[8,116$,} \\
\hline & & & & & 117] \\
\hline Styracaceae & Styrax japonica & Stem bark & Arctiin & $\begin{array}{l}\text { The stem bark has been used to treat inflammatory } \\
\text { diseases. }\end{array}$ & [118] \\
\hline \multirow[t]{2}{*}{ Taxaceae } & Torreya nucifera & Bark & Arctiin, AR & $\begin{array}{l}\text { The fruits are widely used in folk medicine for the } \\
\text { treatment of tapeworm infestation in Korea. }\end{array}$ & [119] \\
\hline & Torreya jackii & Leaves & AR & No medical use has been reported for this species. & [120] \\
\hline Thymelaeaceae & Wikstroemia indica & Whole plant & $\operatorname{AR}(0.06 \%)$ & $\begin{array}{l}\text { Has long been employed as an antipyretic, detoxicant, } \\
\text { expectorant, vermifuge, and abortifacient agent in } \\
\text { clinical practice in China. }\end{array}$ & {$[121]$} \\
\hline
\end{tabular}

Table 2. Summary of the studies on anti-inflammatory effects and related mechanisms of AR.

\begin{tabular}{|c|c|c|c|c|c|}
\hline Model & Cell line/species & Dose & Effect & Mechanism & Ref \\
\hline \multirow[t]{7}{*}{$\begin{array}{l}\text { LPS-induced } \\
\text { inflammation }\end{array}$} & RAW264.7 & 0.01 to $1 \mu \mathrm{mol} / \mathrm{L}$ & Suppression of NO production & $\begin{array}{l}\text { Inhibition of iNOS protein expression; } \\
\text { suppression of IkB } \alpha \text { phosphorylation and } \\
\text { p65 nuclear translocation }\end{array}$ & [30] \\
\hline & & 0.01 to $1 \mu \mathrm{mol} / \mathrm{L}$ & NR & $\begin{array}{l}\text { Decrease of TNF- } \alpha \text { production and mRNA } \\
\text { level; inhibition of binding between AP-1 } \\
\text { and its consensus oligonucleotide; inhibition } \\
\text { of phosphorylation and activation of MAPKs }\end{array}$ & [36] \\
\hline & & 0.1 to $10 \mu \mathrm{mol} / \mathrm{L}$ & $\begin{array}{l}\text { Inhibition of } \mathrm{NO} \text { and } \mathrm{PGE}_{2} \\
\text { production }\end{array}$ & $\begin{array}{l}\text { Reduction of iNOS and COX-2 expression; } \\
\text { inhibition of NF-KB expression and binding; } \\
\text { Suppression of phosphorylation of IKB, IKK } \\
\text { and activation of MAPKs }\end{array}$ & [33] \\
\hline & & 0.3 to $32 \mu \mathrm{mol} / \mathrm{L}$ & Inhibition of NO production & Inhibition of TNF- $\alpha$ production & [22] \\
\hline & & 3 to $100 \mu \mathrm{mol} / \mathrm{L}$ & $\begin{array}{l}\text { Inhibition of iNOS activity; no } \\
\text { inhibition of COX-2 activity }\end{array}$ & $\begin{array}{l}\text { Suppression of iNOS expression; inhibition of } \\
\text { TNF- } \alpha \text { and IL- } 6 \text { production }\end{array}$ & [31] \\
\hline & U937 & 1 to $16 \mu \mathrm{mol} / \mathrm{L}$ & NR & Inhibition of TNF- $\alpha$ production & [22] \\
\hline & $\begin{array}{l}\text { Mice peritoneal } \\
\text { macrophage }\end{array}$ & 10 to $20 \mu \mathrm{mol} / \mathrm{L}$ & NR & $\begin{array}{l}\text { Decrease of IL-1 } 13, \text { IL-6, and TNF- } \alpha \text { level with } \\
\text { increased IL-10 and CD204; inhibition of NF-KB } \\
\text { activation and p } 65 \text { nuclear translocation; } \\
\text { suppression of PI3K and AKT phosphorylation }\end{array}$ & [2] \\
\hline $\begin{array}{l}\text { Silica-induced } \\
\text { inflammation }\end{array}$ & RAW264.7 & 0.1 to $10 \mu \mathrm{mol} / \mathrm{L}$ & Inhibition of ROS production & NR & [25] \\
\hline
\end{tabular}




\begin{tabular}{|c|c|c|c|c|c|}
\hline Model & Cell line/species & Dose & Effect & Mechanism & Ref \\
\hline $\begin{array}{l}\text { Anti-CD3/CD28 } \\
\text { Ab induced } \\
\text { proliferation }\end{array}$ & $\begin{array}{l}\text { Primary human } \\
\text { T lymphocyte }\end{array}$ & 8.25 to $25 \mu \mathrm{mol} / \mathrm{L}$ & $\begin{array}{l}\text { Inhibition of lymphocytes } \\
\text { proliferation }\end{array}$ & $\begin{array}{l}\text { Suppression of IL-2 and IFN-y production and } \\
\text { gene expression; decrease of NF-AT-mediated } \\
\text { reporter gene expression }\end{array}$ & [3] \\
\hline $\begin{array}{l}\text { TGF- } \beta 1 \text {-induced } \\
\text { EMT-like } \\
\text { changes in } \\
\text { renal tubular } \\
\text { epithelial cells }\end{array}$ & $\begin{array}{l}\text { Human proximal } \\
\text { tubular cell line } \\
\text { HK-2 }\end{array}$ & 0.5 to $1 \mu \mathrm{mol} / \mathrm{L}$ & $\begin{array}{l}\text { Protection against } \\
\text { TGF- } \beta 1 \text {-induced MCP-1 } \\
\text { upregulation and the resulting } \\
\text { EMT-like phenotypic changes }\end{array}$ & $\begin{array}{l}\text { Inactivation of the ROS/ERK1/2 MAPK/NF-KB } \\
\text { pathway }\end{array}$ & [122] \\
\hline $\begin{array}{l}\text { TNF- } \alpha \text { induced } \\
\text { inflammation }\end{array}$ & BEAS-2B cells & $50 \mu \mathrm{mol} / \mathrm{L}$ & NR & $\begin{array}{l}\text { Inhibition of PI3K/AKT and Ras/MAPK } \\
\text { pathways; inhibition of NF-KB activation }\end{array}$ & [35] \\
\hline $\begin{array}{l}\text { Acetic acid- } \\
\text { induced } \\
\text { inflammation }\end{array}$ & Rats & $\begin{array}{l}12.5,25, \\
100 \mathrm{mg} / \mathrm{kg}, \mathrm{po}, \\
\text { single dose }\end{array}$ & $\begin{array}{l}\text { Decrease of writhing response } \\
\text { and capillary permeability } \\
\text { accentuation }\end{array}$ & NR & [25] \\
\hline $\begin{array}{l}\text { Arachidonic } \\
\text { acid-induced } \\
\text { ear edema }\end{array}$ & Rats & $\begin{array}{l}0.1-1 \mathrm{mg} / \mathrm{ear} \\
\text { painting, single } \\
\text { dose }\end{array}$ & $\begin{array}{l}\text { Decrease of edema volume, } \\
\text { tissue MPO and EPO activities }\end{array}$ & NR & [25] \\
\hline $\begin{array}{l}\text { Carrageenan- } \\
\text { induced paw } \\
\text { edema }\end{array}$ & Rats & $\begin{array}{l}10,30,100 \mathrm{mg} / \mathrm{kg}, \\
\text { po, single dose }\end{array}$ & Decrease of paw edema volumn & NR & [25] \\
\hline \multirow[t]{2}{*}{$\begin{array}{l}\text { LPS-Induced } \\
\text { acute lung } \\
\text { injury }\end{array}$} & Rats & $\begin{array}{l}30,100 \mathrm{mg} / \mathrm{kg}, \mathrm{iv}, \\
\text { single dose }\end{array}$ & $\begin{array}{l}\text { Reduced histological damage, } \\
\text { myeloperoxidase activity, and } \\
\text { wet-to-dry weight ratio of lung } \\
\text { tissues }\end{array}$ & $\begin{array}{l}\text { Decrease of TNF- } \alpha, \text { IL-1 } 1 \beta \text {, and IL- } 6 \text { levels; } \\
\text { down-regulation of NF-KB and p } 65 \text { expression; } \\
\text { activation of AMPK } \alpha\end{array}$ & [37] \\
\hline & Mice & $\begin{array}{l}50 \mathrm{mg} / \mathrm{kg}, \mathrm{ip}, \\
\text { single dose }\end{array}$ & $\begin{array}{l}\text { Decreased infiltration of } \\
\text { inflammatory cells into BALF; } \\
\text { production of pro-inflammatory } \\
\text { cytokines; reduced the } \\
\text { malondialdehyde level; } \\
\text { increased superoxide dismutase } \\
\text { and catalase activities and } \\
\text { glutathione peroxidase/glutathion } \\
\text { disulfide ratio in the lung }\end{array}$ & $\begin{array}{l}\text { Significantly reduction of NO production and iNOS } \\
\text { expression; enhancement of heme oxygenase-1 } \\
\text { expression, and decrease of MAPKs phosphorylatio } \\
\text { he }\end{array}$ & ion \\
\hline \multirow[t]{2}{*}{$\begin{array}{l}\text { LPS-induced } \\
\text { colitis }\end{array}$} & Mice & $\begin{array}{l}5 \mathrm{mg} / \mathrm{kg}, \text { ip, } \\
\text { single dose }\end{array}$ & NR & $\begin{array}{l}\text { Suppression of blood IL-1 } \beta \text { and TNF- } \alpha \text { level } \\
\text { TNBS-induced colitis }\end{array}$ & [2] \\
\hline & Mice & $\begin{array}{l}\text { 30, } 60 \mathrm{mg} / \mathrm{kg}, \mathrm{po} \text {, } \\
\text { qd, } 3 \text { days }\end{array}$ & $\begin{array}{l}\text { Reduced loss of body weight, } \\
\text { colon shortening, macroscopic } \\
\text { scores and MPO activity }\end{array}$ & $\begin{array}{l}\text { Inhibition of IL-1 } 1 \beta \text {, TNF- } \alpha \text { and IL- } 6 \text { expression and } \\
\text { increase of IL-10 and CD204 expression; inhibition } \\
\text { of NF-KB activation, as well as PI3K, AKT and } \\
\text { IKK } \beta \text { phosphorylation }\end{array}$ & [2] \\
\hline $\begin{array}{l}\text { Dextran } \\
\text { sulphate } \\
\text { sodium-induced } \\
\text { colitis }\end{array}$ & Mice & $\begin{array}{l}25,50 \mathrm{mg} / \mathrm{kg}, \mathrm{po} \\
\mathrm{qd}, 10 \text { days }\end{array}$ & $\begin{array}{l}\text { Reduced loss of body weight, } \\
\text { disease index and histological } \\
\text { damage; recovered intestinal } \\
\text { epithelial cells; decreased } \\
\text { infiltration of neutrophils and } \\
\text { macrophages }\end{array}$ & $\begin{array}{l}\text { Down-regulation of cytokines expressions, } \\
\text { including TNF- } \alpha \text { and IL- } 6 \text { at protein and mRNA } \\
\text { levels; suppression of MAPKs phosphorylation and } \\
\text { NF-KB activation; blockage of Th1 and Th17 } \\
\text { responses; inhibition of mTORC1 associated with } \\
\text { down-regulation of Th1/ Th17 responses }\end{array}$ & $\begin{array}{l}\text { [26, } \\
\text { d23] }\end{array}$ \\
\hline $\begin{array}{l}\text { Convection } \\
\text { enhanced } \\
\text { delivery induced } \\
\text { brain injury }\end{array}$ & Mice & $\begin{array}{l}20,40,80 \mathrm{mg} / \mathrm{kg} \\
\text { po, qd, } 14 \text { days }\end{array}$ & $\begin{array}{l}\text { Reduced brain water content } \\
\text { and hematoma; accelerated } \\
\text { wound closure; reduced number } \\
\text { of allograft inflammatory factor- } \\
\text { and MPO-positive cells }\end{array}$ & $\begin{array}{l}\text { Decrease of number of allograft inflammatory } \\
\text { factor and MPO-positive cells, TNF- } \alpha \text { and IL- } 6 \\
\text { level; Elevation of IL-10 level }\end{array}$ & {$[28]$} \\
\hline
\end{tabular}

Abbreviation: iv: intravenous administration; po: oral administration; ip: intraperitoneal; qd: once daily. NR: not reported.

various disease models, including local edema, colitis, acute lung injury, and brain trauma. AR was effective in relieving symptoms such as writhing response, capillary permeability accentuation, and edema volume in local tissue inflammation of rats induced by various stimulators ${ }^{[25]}$. Protective effects of AR against LPS-induced acute lung injury through suppression of MAPK, HO-1, and iNOS signaling was observed ${ }^{[26,27]}$. Furthermore, AR reduced the infiltration of leukocytes into 
local tissues, a typical hallmark of acute inflammation. This was observed in various colitis mouse models by the decreased activity of myeloperoxidase (MPO), eosinophil peroxidase (EPO), and cluster of differentiation 68 (CD68), indicators of neutrophils, eosinophils and macrophages, respectively ${ }^{[2,26,28]}$. In addition, AR reduced brain water content and hematoma and accelerated wound closure in convection-enhanced delivery induced brain injury in mice through regulation of various inflammatory factors and numbers of MPO-positive cells ${ }^{[28]}$.

The anti-inflammatory effect of AR was first shown to be mediated through the suppression of $\mathrm{NO}$ production via inhibition of inducible nitric oxide synthase (iNOS) at both the expression and activity levels. These findings have been confirmed in multiple in vitro studies that were primarily conducted on a lipopolysaccharide (LPS)-induced inflammatory model of RAW264.7 cells ${ }^{[22,29-32]}$, an immortalized murine macrophage cell line, and on U937 cells ${ }^{[22]}$, a human pro-macrophage cell line. The modulatory effects of AR on cyclooxygenase-2 (Cox-2) ${ }^{[31,33]}$ have also been reported, but there is controversy regarding the effect of AR on Cox2. Although both studies were carried out on the same LPSinduced RAW 267.4 cells, Zhao et al reported that AR did not affect Cox-2 expression or enzyme activity at 3-100 $\mu \mathrm{mol} / \mathrm{L}^{[31]}$, whereas Lee et al found that $0.1 \mu \mathrm{mol} / \mathrm{L}$ of $\mathrm{AR}$ could decrease COX-2 expression and $\mathrm{PGE}_{2}$ production by $26.70 \% \pm 4.61 \%$ and $32.84 \% \pm 6.51 \%$, respectively ${ }^{[33]}$. Other in vitro anti-inflammatory effects of AR include inhibition of LPS-induced primary murine splenocyte proliferation ${ }^{[22]}$, inhibition of anti-CD3/CD28 antibody-induced primary human $\mathrm{T}$ lymphocyte proliferation ${ }^{[3]}$, and polarization of M1 macrophages to M2-like macrophages ${ }^{[2]}$. The anti-inflammatory effect was also confirmed on silica-induced and peptidoglycan-induced inflammatory cell models ${ }^{[25]}$. In addition, AR was reported to have immunomodulatory effects towards type I-IV allergic inflammation ${ }^{[34]}$, as well as inhibiting mast cellmediated allergic responses ${ }^{[35]}$.

Molecular mechanisms accounting for the anti-inflammatory effect of AR have been widely investigated in the past decade. Generally, upon sensing infection or tissue damage, transcription factors such as nuclear factor $\mathrm{\kappa B}(\mathrm{NF}-\mathrm{kB})$ are activated to induce the expression of genes participating in the inflammatory response (eg, iNOS and COX-2). Cytokine-mediated feed-forward loops can amplify and coordinate this inflammatory response ${ }^{[15]}$. The anti-inflammatory effect of AR has been attributed to its potent in vitro and in vivo modulating effects on several important cytokines, such as tumor necrosis factor- $\alpha$ (TNF- $\alpha)^{[2,22,26,28,31,36,37]}$, interleukin-6 (IL-6) ${ }^{[2,26,28,29,31,37]}$, interleukin-1 $\beta$ (IL-1 $\left.\beta\right)^{[2,29,37]}$, and interleukin-10 (IL-10) ${ }^{[2,28]}$. Inhibitory effects of AR on the expression levels of other cytokines, such as interleukin-2 and interferon-y (IFN$\gamma)$, were also found in vitro ${ }^{[3]}$. Multiple upstream mechanisms for the modulating effect of AR on cytokines were proposed. Both in vivo and in vitro studies showed that $A R$ inactivated NF-kB by inhibiting p65 nuclear translocation, suppressing I-k phosphorylation $^{[2,26,30,37]}$, suppressing phosphorylation of mitogen-activated protein kinases $(\mathrm{MAPKs})^{[26,36]}$, and inhibiting phosphorylation of phosphatidylinositide 3-kinases (PI3K) and protein kinase B
$(\mathrm{AKT})^{[2,26]}$. Other proposed mechanisms include suppression of the Janus kinase (JAK)-signal transducer and activator of transcription 3 (STAT3) pathway ${ }^{[4,29]}$, promotion of degradation of iNOS synthase through the carboxyl terminus of Hsc70interacting protein (CHIP)-associated proteasome ${ }^{[32]}$, and activation of adenosine 5'-monophosphate (AMP)-activated protein kinase $(\mathrm{AMPKa})^{[37]}$. However, there are few studies on the anti-inflammatory effects of arctiin. In three studies, arctiin was reported to have similar anti-inflammatory effects to those of AR in vitro and in vivo ${ }^{[33,38,39]}$.

\section{Effect of $A R$ and arctiin against exogenous pathogens}

$\mathrm{AR}$, arctiin, and A lappa also demonstrated inhibitory effects on microorganism (Table 3 ), including viruses and bacteria, common exogenous stimuli for inflammatory responses. Studies attributed the anti-viral effects of A lappa to the major component AR. AR was reported to have strong anti-viral activities against influenza $\mathrm{A}$ in both in vitro and in vivo settings, and the mechanism of the anti-influenza effect of AR was related to the direct inhibitory effect on viral replication ${ }^{[5,6,40]}$. Furthermore, protective effects of AR against more lethal pathogens, such as human immunodeficiency virus and Japanese encephalitis virus, were also reported with in vitro and in vivo models ${ }^{[7,41-43]}$. AR demonstrated inhibitory effects on the bacteria Helicobacter pylori, but this effect was not sufficient to attenuate the gastric carcinogenesis in Mongolian gerbils ${ }^{[44]}$. Other anti-bacterial activities of A lappa against pathogens such as Escherichia coli and Pseudomonas aeruginosa were all demonstrated using the extract of the herb on in vitro disk diffusion models ${ }^{[45-48]}$. In addition, inhibitory effects of A lappa on other microorganisms, such as fungi, were also demonstrated ${ }^{[46]}$. However, whether these effects are attributed to AR and arctiin is still unclear.

\section{Anti-inflammatory activities of AR and arctiin on chronic diseases}

$\mathrm{AR}$ and arctiin have also been associated with beneficial effects on some chronic diseases, such as metabolic disorders and central nervous system dysfunctions, partially due to their anti-inflammatory activity. AR and arctiin demonstrated their effects on ameliorating metabolic disorders in various cell lines ${ }^{[49-51]}, o b / o b$ mice, and streptozotoxin (SZT)-induced diabetic rats $^{[8-10]}$. Neuroprotective effects of AR were demonstrated on cultured neuron cells, cerebral ischemia rats, memory deficit mice, experimental autoimmune encephalomyelitis in mice, $\mathrm{A} \beta$-induced $\mathrm{AD}$ mice, and transgenic Alzheimer's disease mice $^{[11-13,52,53]}$. Multiple mechanisms for these neuroprotective effects were proposed, including scavenging free radicals, down-regulating pro-inflammatory cytokines, regulating AMPK and PPAR- $\gamma /$ ROR- $\gamma$ t signaling, reducing Tau hyperphosphorylation and inhibiting $A \beta$ production ${ }^{[11-13,52-54]}$. In addition, although AR and A lappa demonstrated their potential anti-cancer activities on various cancer cell lines, there is still a lack of sufficient evidence for their anti-cancer activities on in vivo models ${ }^{[21,55-59]}$.

In summary, AR was reported as the most potent bioactive component of A lappa in the majority of studies, while the bioactivities of arctiin were lower than those of AR in most 
Table 3. Summary of the studies on pharmacological effect of AR and arctiin against exogenous pathogens.

\begin{tabular}{|c|c|c|c|c|c|}
\hline Pathogen & Compound & Model & Dose & Findings & Ref \\
\hline \multirow[t]{2}{*}{$\begin{array}{l}\text { Japanese } \\
\text { encephalitis } \\
\text { virus (JEV) }\end{array}$} & AR & BALB/c mice & $10 \mathrm{mg} / \mathrm{kg}$, ip & $\begin{array}{l}\text { AR treatment provided complete protection from JEV infection, } \\
\text { reduced virus titres and demonstrated neuron rescue and gliosis } \\
\text { reducing effects. }\end{array}$ & {$[41]$} \\
\hline & AR & Mouse Neuro2a cells & $0.1 \%$ & AR decreased viral titre. & [41] \\
\hline \multirow{3}{*}{$\begin{array}{l}\text { Human } \\
\text { immunodeficiency } \\
\text { virus (HIV) }\end{array}$} & AR & $\begin{array}{l}\text { HTLV-III B/H9-Jurkat } \\
\text { cell system }\end{array}$ & $0.5 \mu \mathrm{mol} / \mathrm{L}$ & $\begin{array}{l}\text { The expression and reverse transcriptase activity of HIV-1 } \\
\text { proteins p17 and p24, was inhibited by AR. }\end{array}$ & [42] \\
\hline & AR & $\begin{array}{l}\text { 3'-processing and } \\
\text { integration assays }\end{array}$ & $100 \mu \mathrm{mol} / \mathrm{L}$ & $\begin{array}{l}\text { AR suppressed the integration of proviral DNA into the cellular } \\
\text { DNA genome but was inactive in the cleavage (3'-processing) } \\
\text { and integration (strand transfer) assays. }\end{array}$ & [43] \\
\hline & AR & CHME5 cells & $5-20 \mu \mathrm{mol} / \mathrm{L}$ & $\begin{array}{l}\text { AR regulated the upstream PI3K enzyme to abolish the } \\
\text { cytoprotective phenotype of HIV virus type } 1 \text { Tat-expressing } \\
\text { CHME5 cells. }\end{array}$ & [7] \\
\hline \multirow[t]{4}{*}{ Influenza A } & Arctiin & BALB/c mice & $5 \mathrm{mg} / \mathrm{d}$, po & $\begin{array}{l}\text { Lethal infection was decreased, virus production was reduced, } \\
\text { antibody response was elevated by treatment of arctiin. }\end{array}$ & [5] \\
\hline & AR & $\mathrm{NIH}$ mice & $10,100 \mu g / k g, p o$ & $\begin{array}{l}\text { Lung consolidation due to viral infection was significantly inhibited } \\
\text { by AR. Survival time of infected mice was prolonged by AR treatment }\end{array}$ & $\begin{array}{l}{[6]} \\
\text { t. }\end{array}$ \\
\hline & AR & MDCK cells & $5,25,50 \mu \mathrm{mol} / \mathrm{L}$ & $\begin{array}{l}\mathrm{IC}_{50} \text { of } \mathrm{AR} \text { were } 3.8 \mu \mathrm{mol} / \mathrm{L} \text { and } 2.9 \mu \mathrm{mol} / \mathrm{L} \text { in plaque yield } \\
\text { reduction assay. Synergistic effect of } \mathrm{AR} \text { with oseltamivir was found. }\end{array}$ & [5] \\
\hline & $\mathrm{AR}$ & Hemagglutination titer & $6.7-53.6 \mu \mathrm{mol} / \mathrm{L}$ & $\begin{array}{l}\text { Hemagglutination titer was inhibited, indicating direct inhibitory } \\
\text { effect against influenza virus replication of AR. }\end{array}$ & [40] \\
\hline Helicobacter pylori & $\mathrm{AR}$ & Mongolian gerbil & $\begin{array}{l}10 \mu \mathrm{mol} / \mathrm{L}, 0.1 \% \\
\text { in diet }\end{array}$ & $\begin{array}{l}\text { AR showed inhibitory effect of } \mathrm{H} \text {. pylori colonies at } 10 \mu \mathrm{mol} / \mathrm{L} \text {, but } \\
\text { failed to attenuate neoplasia in vivo. }\end{array}$ & [44] \\
\hline $\begin{array}{l}\text { porcine circovirus } \\
\text { type } 2\end{array}$ & AR & Mice & 200 mg/kg, ip & $\begin{array}{l}\text { Significant inhibition of PCV2 proliferation in the lungs, spleens } \\
\text { and inguinal lymph nodes. }\end{array}$ & [124] \\
\hline
\end{tabular}

Abbreviation: ip: intraperitoneal injection; po: oral administration.

reports evaluating both compounds. AR demonstrated potent effects on inflammatory responses. The anti-inflammatory effect of AR may function synergistically with its anti-viral effect to manage some infectious conditions. However, inflammatory responses also have a role in the progression of several chronic diseases, and AR may serve as an auxiliary treatment for these chronic diseases, including metabolic disorders and central nervous system dysfunctions.

\section{Pharmacokinetic properties of AR and arctiin}

Despite the research attention AR has received due to its promising therapeutic potential, biopharmaceutic and pharmacokinetic investigations of $\mathrm{AR}$ and arctiin are rare. In this section, we will discuss the pharmacokinetic properties of arctiin and AR, including the absorption, distribution, metabolism and excretion characteristics, focusing on the biotransformation of arctiin and AR. Furthermore, comparison will be made among the pharmacokinetic profiles of AR after various routes of administration.

\section{Pharmacokinetic properties of arctiin}

AR was regarded as the only metabolite in most in vivo pharmacokinetic studies of arctiin, due to its much higher concentration in plasma compared with that of $\operatorname{arctiin}^{[5,60]}$. However, in vitro incubation studies of arctiin or AR with intestinal content or feces revealed that intestinal microbiota mediated the biotransformation of arctiin to AR in the intestine ${ }^{[61,62]}$, fol- lowed by demethylation and a series of other biotransformation processes leading to the formation of enterolactone (3) ${ }^{[63-65]}$. Wang et al reported three metabolites in rat urine and feces after oral administration of $30 \mathrm{mg} / \mathrm{kg}$ arctiin (1), including AR (2), enterolactone (3) and (2R,3R)-2-(3'-hydroxybenzyl)-3-(3",4"dimethoxybenzyl)-butyrolactone, an intermediate metabolite ${ }^{[66]}$ (Figure 2).

\section{Pharmacokinetic properties of AR}

The pharmacokinetic properties of AR are summarized in Table 4. After oral ingestion, efficient absorption of AR was demonstrated in a Caco-2 cell monolayer transport study and a rat in situ intestinal perfusion model ${ }^{[67,68]}$. The duodenum was found to be the best absorption segment of AR among all the intestinal segments ${ }^{[67]}$. Although the Caco-2 cell monolayer model showed that no significantly active efflux was involved during the absorption of AR, with an efflux ratio of $1.17^{[68]}$, an in situ intestinal perfusion model showed that absorption of AR in the duodenum was significantly improved by co-treatment with the P-glycoprotein (P-gp) inhibitor verapamil ${ }^{[67]}$, suggesting AR is a potential P-gp substrate.

After entering the systemic circulation, AR exhibited a strong binding capacity $(99.8 \%-100 \%)$ to plasma. The high plasma binding was found in various species, including human, beagle dog, and rat ${ }^{[69]}$. The tissue distribution of AR was only investigated after hypodermic or oral administration to rats. After hypodermic injection of $0.806 \mu \mathrm{mol} / \mathrm{kg}$ AR to 


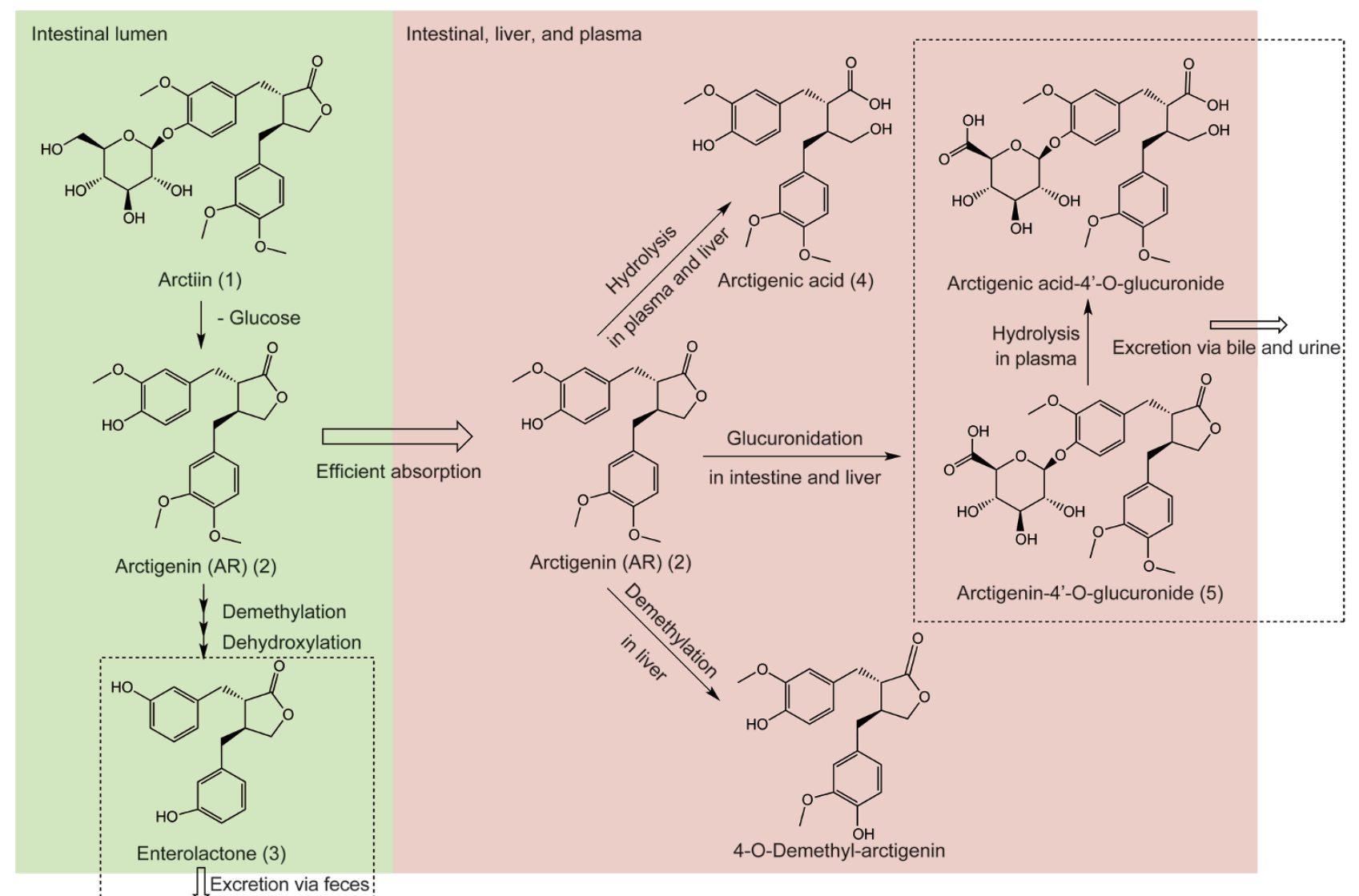

Figure 2. Summary of major in vivo metabolic pathways of AR and arctiin.

rats, the AR concentrations were reduced at $6 \mathrm{~h}$ to approximately $1 / 10$ of their peak values at $0.25 \mathrm{~h}$ in most organs, indicating no accumulation in tissues, and the peak concentration of AR was in the intestine, followed by the heart, liver, pancreas, and kidney ${ }^{[69]}$. After oral administration of $70 \mathrm{mg} / \mathrm{kg}$ $\mathrm{AR}$ to rats, the tissue concentration of AR peaked at $30 \mathrm{~min}$ and was quickly eliminated within $4 \mathrm{~h}$, and the concentration of AR was highest in the spleen, followed by the liver and the other organs ${ }^{[70]}$.

AR was eliminated via extensive metabolism to various metabolites. The dominant metabolic pathways of AR are summarized in Figure 2. In vitro incubation of AR with the intestinal microbiota demonstrated that similar to acrtiin, AR can be biotransformed into a series of demethylation and dehydroxylation products, such as 3 '-demethylarctigenin, 3'-demethyl-4'-dehydroxyarctigenin, and eventually to the enterolactone (3) anaerobically within $24 \mathrm{~h}^{[61,65,71]}$. In rats, extensive first-pass metabolism of AR occurred in both the intestine and liver, with the formation of two major in vivo metabolites, namely, arctigenic acid (4) and arctigenin-4'-Oglucuronide (5) ${ }^{[6,72-74]}$. Further in vitro and clinical studies confirmed that similar biotransformation also occurred in humans. The hydrolysis of AR was mediated by human paraoxonase 1 in plasma ${ }^{[73]}$, and glucuronidation of AR was mediated by UGT1A9, UGT2B7 and UGT2B17 in the liver and intestine $^{[7]}$. A phase I clinical trial of the herbal product GBS-
01 on pancreatic cancer patients demonstrated that after oral administration of GBS-01 at a dose of $12 \mathrm{~g}$ AR per person, the area under the plasma concentration versus time curve (AUC) of arctigenin-glucuronide was almost 1000 times higher than that of $\mathrm{AR}^{[75]}$. Notably, the extent of metabolism of AR might be different between species. As reported by Li et al, approximately $62 \%, 3.7 \%, 25.9 \%$ and $15.7 \%$ of the AR remained after incubation in human, monkey, dog, and rat liver microsomes for $90 \mathrm{~min}^{[69]}$. Other minor in vivo metabolites found in SD rats include 4-O-demethylarctigenin, arctigenin 4-O'-sulfate, arctigenic acid-4'-O-glucuronide, and 4-O-demethyl-arctigenin-4,4'-O-di-glucuronide ${ }^{[72,73]}$. Following rapid formation, fast elimination of the two major metabolites was observed after both intravenous and oral administration of AR to rats. Several glucuronidation products of AR, including arctigenin4'-O-glucuronide (5), were excreted via bile, with potential enterohepatic circulation suggested ${ }^{[72]}$. These complex metabolic pathways of AR were described and verified by an integrated semi-mechanistic pharmacokinetic model of rats ${ }^{[72]}$ and warrant further verification in human trials.

Due to the extensive first-pass metabolism of AR, it is likely that most AR, either as single compound or as active component in herbal preparations, would be quickly metabolized after oral administration. As shown in Table 5, after oral administration, the plasma concentrations of AR were very low and even undetectable in various animal models, sug- 
Table 4. Summary of absorption, distribution, metabolism and elimination of AR.

\begin{tabular}{|c|c|c|c|}
\hline Model & Dose & Findings & Ref \\
\hline \multicolumn{4}{|l|}{ Absorption } \\
\hline Caco-2 cell monolayer & $50 \mu \mathrm{g} / \mathrm{mL}$ & $\begin{array}{l}\text { AR efficiently passed through the cell monolayer with } P_{\text {app }} \text { of }(1.76 \pm 0.48) \times 10^{-5} \text { (apical to } \\
\text { basolateral) and }(1.50 \pm 0.61) \times 10^{-5} \text { (basolateral to apical). }\end{array}$ & [68] \\
\hline $\begin{array}{l}\text { In situ SD rat intestinal } \\
\text { perfusion model }\end{array}$ & $25 \mu \mathrm{g} / \mathrm{mL}$ & Efficient absorption of AR was observed with extensive intestinal first-pass metabolism demonstrated. & [68] \\
\hline $\begin{array}{l}\text { In situ intestinal } \\
\text { perfusion on normal } \\
\text { and diabetic SD rats }\end{array}$ & $5,10,20 \mu \mathrm{g} / \mathrm{mL}$ & $\begin{array}{l}\text { AR belongs to easily absorbed agents. Duodenum was the best absorption segment of AR. The } P_{\text {eff }} \text { and } \\
K_{a} \text { of AR were increased by } 60 \% \text { and } 52 \% \text { in duodenum with co-treatment of verapamil. The absorption } \\
\text { of AR was promoted in diabetic rats. }\end{array}$ & [67] \\
\hline \multicolumn{4}{|c|}{ ( } \\
\hline $\begin{array}{l}\text { In vitro plasma } \\
\text { incubation }\end{array}$ & $\begin{array}{l}0.0672,0.269 \\
1.075 \mu \mathrm{mol} / \mathrm{L}\end{array}$ & $\begin{array}{l}\text { AR exhibited a strong binding capacity }(99.8 \%-100 \%) \text { with plasma, including human, beagle dog, and } \\
\text { rat. }\end{array}$ & [69] \\
\hline Wistar rat & $\begin{array}{l}0.806 \mu \mathrm{mol} / \mathrm{kg} \\
\text { in }\end{array}$ & $\begin{array}{l}\text { AR concentration in the intestine was the highest, followed by heart, liver, pancreas, and kidney. } \\
\text { No accumulation of AR in tissues after } 6 \mathrm{~h} \text {. }\end{array}$ & [69] \\
\hline SD rat & $\begin{array}{l}30,50 \\
70 \mathrm{mg} / \mathrm{kg}, \text { po }\end{array}$ & $\begin{array}{l}\text { AR was rapidly distributed into organs, and } C_{\max } \text { in tissues was observed at } 30 \mathrm{~min} \text {. The content of } \\
A R \text { in spleen was the highest. }\end{array}$ & [70] \\
\hline \multicolumn{4}{|c|}{ Metabolism and elimination } \\
\hline $\begin{array}{l}\text { Human fecal inoculum } \\
\text { incubation }\end{array}$ & $\begin{array}{l}0.2 \text { to } \\
0.35 \mathrm{mmol} / \mathrm{L}\end{array}$ & $\begin{array}{l}\text { Three metabolites of AR were identified under anaerobic condition: enterolactone (3), } \\
\text { 3'-demethyl-4'-dehydroxyarctigenin and 3'-demethylarctigenin. }\end{array}$ & [65] \\
\hline $\begin{array}{l}\text { Eubacterium ARC-2 } \\
\text { incubation }\end{array}$ & $0.6 \mathrm{mmol} / \mathrm{L}$ & $\begin{array}{l}\text { After 24-h incubation, AR was transformed to } 4^{\prime}, 4^{\prime} \text {-dihydroxylenterolatone through } 3 \text { types of } \\
\text { demethylation products under anaerobic condition. }\end{array}$ & {$[61,71]$} \\
\hline $\begin{array}{l}\text { Rat intestinal content } \\
\text { solution }\end{array}$ & & $\begin{array}{l}\text { After 4-h incubation, AR was stable in rat small and large intestinal content solution, while arctigenic } \\
\text { acid was converted back to arctigenin in rat large intestinal content. All three glucuronides, were } \\
\text { hydrolysed back to corresponding parent compounds. }\end{array}$ & [72] \\
\hline $\begin{array}{l}\text { In situ SD rat intestinal } \\
\text { perfusion model }\end{array}$ & $25 \mu \mathrm{g} / \mathrm{mL}$ & $\begin{array}{l}\text { Extensive intestinal first-pass metabolism of AR to arctigenic acid (4) and arctigenin-4'-0-glucuronide } \\
\text { (5) was identified. }\end{array}$ & [68] \\
\hline $\begin{array}{l}\text { Human recombinant } \\
\text { paraoxonase } 1\end{array}$ & $\begin{array}{l}0.27 \text { to } \\
134.4 \mu \mathrm{mol} / \mathrm{L}\end{array}$ & Paraoxonase 1 was confirmed to be the enzyme responsible for AR hydrolysis. & [73] \\
\hline $\begin{array}{l}\text { V79 Chinese hamster } \\
\text { cells with rat Cyp2b1 }\end{array}$ & $1 \mathrm{mmol} / \mathrm{L}$ & AR was converted to 3'-demethyl-arctigenin in cells expressing rat Cyp2b1. & [125] \\
\hline $\begin{array}{l}\text { Rat liver/intestine } \\
\text { microsome }\end{array}$ & $\begin{array}{l}0.269 \text { to } \\
67.2 \mu \mathrm{mol} / \mathrm{L}\end{array}$ & $\begin{array}{l}\text { Extensive glucuronidation of AR was observed in both liver and intestine microsome. No } \\
\text { further glucuronidation or demethylation of arctigenic acid (4) in liver and intestine microsome. }\end{array}$ & [72] \\
\hline $\begin{array}{l}\text { Rat liver cytosol } \\
\text { incubation }\end{array}$ & $10 \mathrm{nmol} / \mathrm{L}$ & 3'-Demethyl-arctigenin was converted back to AR. & [126] \\
\hline $\begin{array}{l}\text { Human liver/intestine } \\
\text { microsomes }\end{array}$ & $100 \mu \mathrm{mol} / \mathrm{L}$ & $\begin{array}{l}\text { AR was metabolized to 4'-O-glucuronide (5) in human liver and intestinal microsome mainly via } \\
\text { UGT1A9, UGT2B7 and UGT2B17. }\end{array}$ & [74] \\
\hline $\begin{array}{l}\text { Human, monkey, dog, } \\
\text { and rat liver microsome }\end{array}$ & $100 \mu \mathrm{mol} / \mathrm{L}$ & $\begin{array}{l}\text { Around } 62 \%, 3.7 \%, 25.9 \% \text { and } 15.7 \% \text { of AR remained after incubated in human, monkey, dog, and } \\
\text { rat liver microsome for } 90 \text { min. }\end{array}$ & [69] \\
\hline SD rats & $3 \mathrm{mg} / \mathrm{kg}$, po & $\begin{array}{l}\text { Arctigenic acid (4) and arctigenin-4'-0-glucuronide (5) was identified as major metabolites in rat } \\
\text { plasma after oral administration of AR. 4-0-demethylarctigenin was also identified in vivo. }\end{array}$ & [73] \\
\hline SD rats & $\begin{array}{l}0.48 \text { to } \\
2.4 \mathrm{mg} / \mathrm{kg} \text {, iv; } \\
2.4 \text { to } \\
12 \mathrm{mg} / \mathrm{kg}, \text { po }\end{array}$ & $\begin{array}{l}\text { Rapid formation of arctigenic acid (4) and arctigenin-4'-0-glucuronide }(\mathbf{5}) \text { with quick elimination of } \\
\text { both parent and metabolites were observed after both intravenous and oral administrations. No } \\
\text { quantifiable AR was identified after oral administration due to extensive first-pass metabolism }\end{array}$ & [72] \\
\hline SD rats & $0.96 \mathrm{mg} / \mathrm{kg}$, iv & $\begin{array}{l}\text { Arctigenin-4'-0-glucuronide (5), arctigenic acid-4'-0-glucuronide, 4-0-demethyl-arctigenin } \\
-4,4^{\prime}-0 \text {-di-glucuronide, and trace amount of arctigenic acid (4) were found in bile at 0-15 min. }\end{array}$ & [72] \\
\hline Wistar rat & $0.806 \mu \mathrm{mol} / \mathrm{kg}$ in & $\begin{array}{l}\text { Within } 72 \mathrm{~h} \text { after drug-delivery, the urine accumulative excretion ratio was } 1.93 \% \text { and the excretory } \\
\text { amount of AR in faeces and bile were } 0.248 \% \text { and } 0.182 \% \text {, respectively. }\end{array}$ & [69] \\
\hline
\end{tabular}

Abbreviation: iv: intravenous administration; in: hypodermic injection; po: oral administration.

gesting poor oral bioavailability. The pharmacokinetic profile of AR in humans after oral administration was investigated in a phase I clinical trial of the herbal product GBS-01. After oral administration of GBS-01 at a dose of $12 \mathrm{~g}$ AR per person, the peak concentration of AR in the plasma of the pancreatic cancer patients was $66.56 \pm 26.81 \mathrm{ng} / \mathrm{mL}$, and the AUC was $487.97 \pm 368.86 \mathrm{ng}^{*} \mathrm{~h} / \mathrm{mL}^{[75]}$. Given the low molecular weight of $\mathrm{AR}$ and its high permeability demonstrated in the absorption models, the poor oral bioavailability of AR should be mainly due to its extensive first-pass metabolism rather than limita- 
Table 5. Pharmacokinetic parameters of AR after different routes of administration in rat, dog, and human.

\begin{tabular}{|c|c|c|c|c|c|c|c|c|}
\hline \multirow[t]{2}{*}{ Species } & \multirow[t]{2}{*}{ Route } & \multirow[t]{2}{*}{ Dose $(\mu \mathrm{mol} / \mathrm{kg})$} & \multicolumn{5}{|c|}{ Pharmacokinetic parameters } & \multirow[t]{2}{*}{ Ref } \\
\hline & & & $C_{\max }(\mu \mathrm{mol} / \mathrm{L})$ & $T_{\max }(\min )$ & $T_{1 / 2}(\min )$ & $\begin{array}{l}\text { AUC } \\
(\mathrm{min} * \mu \mathrm{mol} / \mathrm{L})\end{array}$ & Bioavailability & \\
\hline \multirow[t]{7}{*}{ Beagle dogs } & iv & 0.403 & N/A & $\mathrm{N} / \mathrm{A}$ & $96 \pm 24.84$ & $15.64 \pm 2.08^{\mathrm{a}}$ & $\mathrm{N} / \mathrm{A}$ & [69] \\
\hline & $\mathrm{sl}$ & $0.20(2.687 \mu \mathrm{mol} / \mathrm{dog})$ & $0.04 \pm 0.01$ & $60 \pm 16.44$ & $61.8 \pm 19.26$ & $6.56 \pm 1.16^{\mathrm{a}}$ & $\mathrm{N} / \mathrm{A}$ & \\
\hline & & 0.403 (5.374 $\mu \mathrm{mol} / \mathrm{dog})$ & $0.07 \pm 0.24$ & $112 \pm 53.64$ & $70.8 \pm 24.36$ & $12.01 \pm 2.26^{\mathrm{a}}$ & $72.5 \%$ & \\
\hline & & 0.81 (10.748 $\mu \mathrm{mol} / \mathrm{dog})$ & $0.10 \pm 0.02$ & $130.2 \pm 70.20$ & $84 \pm 34.98$ & $23.22 \pm 3.06^{\mathrm{a}}$ & $\mathrm{N} / \mathrm{A}$ & \\
\hline & in & 0.134 & $0.03 \pm 0.01$ & $60 \pm 0$ & $94.8 \pm 31.74$ & $4.76 \pm 0.75^{\mathrm{a}}$ & $\mathrm{N} / \mathrm{A}$ & \\
\hline & & 0.403 & $0.11 \pm 0.03$ & $70.2 \pm 15.48$ & $74.4 \pm 12.18$ & $16.93 \pm 5.42^{\mathrm{a}}$ & $108 \%$ & \\
\hline & & 1.209 & $0.25 \pm 0.04$ & $75 \pm 16.44$ & $117 \pm 25.44$ & $35.63 \pm 4.21^{\mathrm{a}}$ & $\mathrm{N} / \mathrm{A}$ & \\
\hline \multirow[t]{3}{*}{ Wistar rats } & iv & 2.687 & N/A & $\mathrm{N} / \mathrm{A}$ & $217.8 \pm 74.04$ & $66.26 \pm 18.7^{\mathrm{a}}$ & $\mathrm{N} / \mathrm{A}$ & [69] \\
\hline & in & 2.687 & $1.26 \pm 0.30$ & $15 \pm 0$ & $116.4 \pm 21.72$ & $77.87 \pm 24.67^{\mathrm{a}}$ & $116 \%$ & \\
\hline & po & 2.687 & \multicolumn{6}{|c|}{ Concentrations were lower than the lowest limit of quantitation at most time points. } \\
\hline Wistar rats & iv & 0.8 & $0.87 \pm 0.18$ & $\mathrm{~N} / \mathrm{A}$ & $40.8 \pm 10.0$ & $13.1 \pm 3.6^{\mathrm{b}}$ & N/A & [127] \\
\hline \multirow[t]{4}{*}{ SD rats } & iv & 0.32 & N/A & $\mathrm{N} / \mathrm{A}$ & $9.35 \pm 2.15$ & $9.32 \pm 2.80^{\mathrm{a}}$ & $\mathrm{N} / \mathrm{A}$ & [72] \\
\hline & & 0.64 & $\mathrm{~N} / \mathrm{A}$ & $\mathrm{N} / \mathrm{A}$ & $13.4 \pm 2.2$ & $19.4 \pm 2.9^{\mathrm{a}}$ & $\mathrm{N} / \mathrm{A}$ & \\
\hline & & 1.61 & $\mathrm{~N} / \mathrm{A}$ & $\mathrm{N} / \mathrm{A}$ & $13.0 \pm 1.8$ & $54.1 \pm 8.1^{\mathrm{a}}$ & $\mathrm{N} / \mathrm{A}$ & \\
\hline & po & $1.61,3.22,8.16$ & \multicolumn{6}{|c|}{ No quantifiable AR was determined. } \\
\hline \multirow[t]{2}{*}{ SD rats } & iv & 27 & $\mathrm{~N} / \mathrm{A}$ & $\mathrm{N} / \mathrm{A}$ & $627.6 \pm 214.8$ & $199.8 \pm 49.51^{\mathrm{a}}$ & $\mathrm{N} / \mathrm{A}$ & [67] \\
\hline & po & 538 & $0.34 \pm 0.04$ & $4.32 \pm 5.46$ & $414.6 \pm 107.4$ & $116.18 \pm 38.69^{a}$ & $\mathrm{~N} / \mathrm{A}$ & \\
\hline \multirow[t]{2}{*}{ Diabetic rats } & iv & 27 & $\mathrm{~N} / \mathrm{A}$ & $\mathrm{N} / \mathrm{A}$ & $469.2 \pm 227.4$ & $151.05 \pm 46.84^{\mathrm{a}}$ & $\mathrm{N} / \mathrm{A}$ & [67] \\
\hline & po & 538 & $1.22 \pm 0.45$ & $3.42 \pm 0.9$ & $322.8 \pm 106.2$ & $197.99 \pm 48.28^{a}$ & $\mathrm{~N} / \mathrm{A}$ & \\
\hline Human with & po & 134 (3 g/person) & $0.05 \pm 0.01$ & $60 \pm 30$ & 430.8 & $40.1 \pm 33.3^{b}$ & $\mathrm{~N} / \mathrm{A}$ & [75] \\
\hline pancreatic & & 269 (6 g/person) & $0.07 \pm 0.02$ & $30 \pm 0$ & $183.6 \pm 176.4$ & $23.0 \pm 9.2^{b}$ & $\mathrm{~N} / \mathrm{A}$ & \\
\hline cancer & & 538 (12 g/person) & $0.18 \pm 0.07$ & $52.2 \pm 37.2$ & $340.8 \pm 380.4$ & $78.7 \pm 59.5^{\mathrm{b}}$ & $\mathrm{N} / \mathrm{A}$ & \\
\hline
\end{tabular}

Abbreviation: iv: intravenous administration; sl: sublingual administration; in: hypodermic injection; po: oral administration. N/A: not applicable. a: $\mathrm{AUC}_{0-\infty} ;{ }^{\mathrm{b}}: \mathrm{AUC}_{0-\mathrm{t}}$.

tions of membrane permeability. Thus, delivering AR through alternative administration routes might be plausible to bypass the first-pass metabolism and improve its bioactivities. Alternative routes for administration of $A R$, including hypodermic injection and sublingual administration, were tested on experimental animals. The results demonstrated substantially improved AUC and bioavailability of AR after hypodermic or sublingual administration compared with that from the oral administration (Table 5) ${ }^{[69]}$. These results suggested that optimization of the administration routes for AR may potentially improve its therapeutic efficacy by increasing the systemic and target organ exposure. Further pharmacokinetic/pharmacodynamic studies of AR after different routes of administration are warranted.

\section{Clinical usages}

As described previously, AR and arctiin served as marker compounds in the quality control of numerous proprietary Chinese medicines. Most of these products are for treatment of common cold, flu and related symptoms, such as various dosage forms of Yinqiaojiedu decoction ${ }^{[76-78]}$, Lingyang ganmao decoction ${ }^{[79,80]}$ and Fengreganmao granules ${ }^{[81,82]}$. Despite its popularity, Fructus Arctii is not commonly used alone. Therefore, reports on the clinical trials of AR, arctiin or A lappa alone are rather limited. As summarized in Table 6, only four clinical trials were identified for evaluation of the therapeutic effects of AR, arctiin or A lappa, with diverse indications. Despite their high Jadad scores ( 2 out of 3 received full score of 5$)^{[83]}$, three randomized controlled trials demonstrating the efficacy of arctiin (0.5-1 g, t.i.d.) or Fructus Arctii (20 g, t.i.d.) against diabetic nephropathy were actually reported by the same group, with a similar study design and dose regiments ${ }^{[84-86]}$. A recent phase I clinical study co-sponsored by the Japanese National Institute for Cancer Research and Kracie Pharmaceutical Co, Ltd confirmed the safety of an oral product containing a high content of AR (GBS-01) (dose equal to 3 to $12 \mathrm{~g}$ daily) ${ }^{[75]}$. Moreover, a study protocol for evaluating A lappa-containing moisturizing cream for dry skin and itch relief in a randomized, double-blind, placebo-controlled trial was published $^{[87]}$. Similarly, A lappa was also demonstrated to effectively treat acne vulgaris in a recent uncontrolled observational interventional study in India ${ }^{[88]}$. The anti-inflammatory effects of AR, arctiin or A lappa have not yet been confirmed in the clinic. Further randomized controlled trials are needed to evaluate the therapeutic efficacy of AR and arctiin.

\section{Conclusions}

Inflammatory responses are an important part of various acute 
Table 6. Summary of clinical trials on AR- or arctiin-containing products.

\begin{tabular}{|c|c|c|c|c|c|c|c|c|}
\hline \multirow[t]{2}{*}{$\begin{array}{l}\text { Diabetic } \\
\text { nephropathy }\end{array}$} & $\begin{array}{l}\text { Fructus } \\
\text { Arctii } \\
\text { powder }\end{array}$ & $\begin{array}{l}\text { Randomized } \\
\text { controlled }\end{array}$ & 2 & $\begin{array}{l}\text { Placebo: } 61 ; \\
\text { Treatment: } 60\end{array}$ & 20 g, t.i.d. & 8 weeks & $\begin{array}{l}\text { Urinary albumin excretion rate } \\
\text { (UAER) and } 24 \text { h quantitative } \\
\text { examination of urinary protein (UPQ) } \\
\text { were improved by the treatment, } \\
\text { which was significantly better } \\
\text { than placebo }(P<0.001) \text {. }\end{array}$ & [86] \\
\hline & $\begin{array}{l}\text { Arctiin } \\
\text { Granule }\end{array}$ & $\begin{array}{l}\text { Randomized } \\
\text { double blind } \\
\text { controlled }\end{array}$ & 5 & $\begin{array}{l}\text { Placebo: 102; } \\
\text { Treatment: } 307\end{array}$ & $\begin{array}{l}500 \mathrm{mg} / \text { dose, } \\
\text { t.i.d. }\end{array}$ & 8 weeks & $\begin{array}{l}\text { The treatment efficacy of arctiin granule } \\
\text { was better than those of placebo }(P<0 . \\
\text { UAER and UPQ were improved by the } \\
\text { treatment }(P<0.05) \text {. }\end{array}$ & 01). \\
\hline
\end{tabular}

Abbreviation: b.i.d.: twice a day; t.i.d.: three times a day; qd: once daily.

and chronic disease conditions. AR, as the most potent bioactive component of A lappa with anti-inflammatory activities, is a promising therapeutic compound against acute inflammation as well as several chronic diseases. However, pharmacokinetic investigations suggested that the extensive firstpass metabolism of AR would hinder its in vivo and clinical efficacy after oral administration. To optimize the in vivo and clinical efficacy of AR, alternative administration routes other than oral administration are suggested. AR could be delivered through sublingual or buccal routes that allow rapid onset of the treatment of acute inflammation and influenza; transdermal routes for the treatment of skin conditions; and the intranasal route for targeting central nervous system dysfunctions. In addition, considering the extensive first-pass metabolism of $\mathrm{AR}$ and the higher plasma concentrations of metabolites compared with parent compound observed, the potential pharmacological effects of the metabolites of AR should be studied. Further reports with simultaneous monitoring of pharmacokinetics and pharmacological properties are essential for a better understanding of the effects of AR.

\section{Acknowledgements}

This work is supported by Direct Grant 3800005 from the Chinese University of Hong Kong and research fund 7010213 from the Health Authority of Hong Kong, China.

\section{References}

1 China Pharmacopoeia Commission, Pharmacopoeia of the People's Republic of China, Part 1. People's Medical Publishing House 2010. Beijing, China.

2 Hyam SR, Lee IA, Gu W, Kim KA, Jeong JJ, Jang SE, et al. Arctigenin ameliorates inflammation in vitro and in vivo by inhibiting the $\mathrm{PI} 3 \mathrm{~K} / \mathrm{AKT}$ pathway and polarizing M1 macrophages to M2-like macrophages. Eur J Pharmacol 2013; 708: 21-9.

3 Tsai WJ, Chang CT, Wang GJ, Lee TH, Chang SF, Lu SC, et al. Arctigenin from Arctium lappa inhibits interleukin-2 and interferon gene expression in primary human T lymphocytes. Chin Med 2011; 6: 12.

4 Kou XJ, Qi SM, Dai WX, Luo L, Yin ZM. Arctigenin inhibits lipopolysaccharide-induced iNOS expression in RAW264.7 cells through suppressing JAK-STAT signal pathway. Int Immunopharmacol 2011; 11: 1095-102.

5 Hayashi K, Narutaki K, Nagaoka Y, Hayashi T, Uesato S. Therapeutic effect of arctiin and arctigenin in immunocompetent and immunocompromised mice infected with influenza A virus. Biol Pharm Bull 2010; 33: 1199-205.

6 Yang Z, Liu N, Huang B, Wang Y, Hu Y, Zhu Y. Effect of anti-influenza virus of arctigenin in vivo. Zhongyaocai 2005; 28: 1012-4.

7 Kim Y, Hollenbaugh JA, Kim DH, Kim B. Novel PI3K/Akt inhibitors screened by the cytoprotective function of humanimmunodeficiency virus type 1 Tat. PLoS One 2011; 6: e21781.

8 Cho SH, Rhee SJ, Choi SW, Choi Y. Effects of forsythia fruit extracts and lignan on lipid metabolism. Biofactors 2004; 22: 161-3.

9 Li X, Liu C, Wei J. The effect of amioguanidine and Arctium lappa on renal tissue nonenzymatic glycation and apoptosis in diabetic rats. Linchuang Heli Yongyao Zazhi 2011; 4: 19-20.

10 Lu LC, Zhou W, Li ZH, Yu CP, Li CW, Luo MH, et al. Effects of arctiin on streptozotocin-induced diabetic retinopathy in Sprague-Dawley rats. Planta Med 2012; 78: 1317-23.

11 Zhu Z, Yan J, Jiang W, Yao XG, Chen J, Chen L, et al. Arctigenin effectively ameliorates memory impairment in Alzheimer's disease model mice targeting both beta-amyloid production and clearance. J Neurosci 2013; 33: 13138-49.

12 Fan T, Jiang WL, Zhu J, Feng Zhang Y. Arctigenin protects focal cerebral 
ischemia-reperfusion rats through inhibiting neuroinflammation. Biol Pharm Bull 2012; 35: 2004-9.

13 Jang YP, Kim SR, Choi YH, Kim J, Kim SG, Markelonis GJ, et al. Arctigenin protects cultured cortical neurons from glutamate-induced neurodegeneration by binding to kainate receptor. J Neurosci Res 2002; 68: 233-40.

14 Sherwood ER, Toliver-Kinsky T. Mechanisms of the inflammatory response. Best Pract Res Clin Anaesthesiol 2004; 18: 385-405.

15 Tabas I, Glass CK. Anti-inflammatory therapy in chronic disease: challenges and opportunities. Science 2013; 339: 166-72.

16 Shao J, Guo M, Yu X, Zhao L, Duan W. Determination of total lignanoids and arctinin in different parts of Arctium lappa L. Zhongguo Xiandai Yingyong Yaoxue 2012; 29: 506-8.

17 Shao J, Ni JN, Zhao L, Yu XH, Duan WD. Comparative study of content of arctiin in burdock fruit of seven different place. Gansu Zhongyi Xueyuan Xuebao 2009; 26: 41-3.

18 Yuan Y, Dou D, Kang T. Evaluating the quality of Arctiin Lappa L with different origins. Shijie Kexue Jishu-Zhongyiyao Xiandaihua 2008; 10: $75-7$.

19 Shoeb M, Celik S, Jaspars M, Kumarasamy Y, Macmanus SM, Nahar L, et al. Isolation, structure elucidation and bioactivity of schischkiniin, a unique indole alkaloid from the seeds of Centaurea schischkinii. Tetrahedron 2005; 61: 9001-6.

20 Paska C, Innocenti G, Kunvari M, Laszlo M, Szilagyi A. Lignan production by Ipomoea cairica callus cultures. Phytochemistry 1999; 52: 879-83.

21 Awale S, Lu J, Kalauni SK, Kurashima Y, Tezuka Y, Kadota S, et al. Identification of arctigenin as an antitumor agent having the ability to eliminate the tolerance of cancer cells to nutrient starvation. Cancer Res 2006; 66: 1751-7.

22 Cho JY, Kim AR, Yoo ES, Baik KU, Park MH. Immunomodulatory effect of arctigenin, a lignan compound, on tumour necrosis factoralpha and nitric oxide production, and lymphocyte proliferation. J Pharm Pharmacol 1999; 51: 1267-73.

23 Sohn EH, Jang SA, Joo H, Park S, Kang SC, Lee CH, et al. Anti-allergic and anti-inflammatory effects of butanol extract from Arctium Lappa L. Clin Mol Allergy 2011; 9: 4.

$24 \mathrm{Kim} \mathrm{E}$, Li G, Chai O, Song C. Inhibitory effect of Arctium lappa Linne on compound 48/80-induced mast cell activation and vascular permeability. Korean J Phys Anthropol 2004; 17: 55-66.

25 Kang HS, Lee JY, Kim CJ. Anti-inflammatory activity of arctigenin from Forsythiae Fructus. J Ethnopharmacol 2008; 116: 305-12.

26 Wu X, Yang Y, Dou Y, Ye J, Bian D, Wei Z, et al. Arctigenin but not arctiin acts as the major effective constituent of Arctium lappa $L$ fruit for attenuating colonic inflammatory response induced by dextran sulfate sodium in mice. Int Immunopharmacol 2014; 23: 505-15.

27 Zhang WZ, Jiang ZK, He BX, Liu XB. Arctigenin protects against Lipopolysaccharide-induced pulmonary oxidative stress and inflammation in a mouse model via suppression of MAPK, HO-1, and iNOS signaling. Inflammation 2015; 38: 1406-14.

28 Song J, Li N, Xia Y, Gao Z, Zou SF, Kong L, et al. Arctigenin treatment protects against brain damage through an anti-inflammatory and anti-apoptotic mechanism after needle insertion. Front Pharmacol 2016; 7: 182.

29 Yao X, Zhu F, Zhao Z, Liu C, Luo L, Yin Z. Arctigenin enhances chemosensitivity of cancer cells to cisplatin through inhibition of the STAT3 signaling pathway. J Cell Biochem 2011; 112: 2837-49.

30 Cho MK, Park JW, Jang YP, Kim YC, Kim SG. Potent inhibition of lipopolysaccharide-inducible nitric oxide synthase expression by dibenzylbutyrolactone lignans through inhibition of I-kappaBalpha phosphorylation and of p65 nuclear translocation in macrophages.
Int Immunopharmacol 2002; 2: 105-16.

31 Zhao F, Wang L, Liu K. In vitro anti-inflammatory effects of arctigenin, a lignan from Arctium lappa L, through inhibition on iNOS pathway. J Ethnopharmacol 2009; 122: 457-62.

32 Yao X, Li G, Lü C, Xu H, Yin Z. Arctigenin promotes degradation of inducible nitric oxide synthase through CHIP-associated proteasome pathway and suppresses its enzyme activity. Int Immunopharmacol 2012; 14: 138-44.

33 Lee JY, Cho BJ, Park TW, Park BE, Kim SJ, Sim SS, et al. Dibenzylbutyrolactone lignans from Forsythia koreana fruits attenuate lipopolysaccharide-induced inducible nitric oxide synthetase and cyclooxygenase-2 expressions through activation of nuclear factor-b and mitogen-activated protein kinase in RAW264.7 cells. Biol Pharm Bull 2010; 33: 1847-53.

34 Lee JY, Kim CJ. Arctigenin, a phenylpropanoid dibenzylbutyrolactone lignan, inhibits type I-IV allergic inflammation and pro-inflammatory enzymes. Arch Pharm Res 2010; 33: 947-57.

35 Hou Y, Nie Y, Cheng B, Tao J, Ma X, Jiang M, et al. Qingfei Xiaoyan Wan, a traditional Chinese medicine formula, ameliorates Pseudomonas aeruginosa-induced acute lung inflammation by regulation of $\mathrm{PI} 3 \mathrm{~K} / \mathrm{AKT}$ and Ras/MAPK pathways. Acta Pharm Sin B 2016; 6: 212-21.

36 Cho MK, Jang YP, Kim YC, Kim SG. Arctigenin, a phenylpropanoid dibenzylbutyrolactone lignan, inhibits MAP kinases and AP-1 activation via potent MKK inhibition: the role in TNF-alpha inhibition. Int Immunopharmacol 2004; 4: 1419-29.

37 Shi X, Sun H, Zhou D, Xi H, Shan L. Arctigenin attenuates lipopolysaccharide-induced acute lung injury in rats. Inflammation 2015; 38: 623-31.

38 Park SY, Hong SS, Han XH, Hwang JS, Lee D, Ro JS, et al. Lignans from Arctium lappa and their inhibition of LPS-induced nitric oxide production. Chem Pharm Bull 2007; 55: 150-2.

39 Wu JG, Wu JZ, Sun LN, Han T, Du J, Ye Q, et al. Ameliorative effects of arctiin from Arctium lappa on experimental glomerulonephritis in rats. Phytomedicine 2009; 16: 1033-41.

40 Gao Y, Dong X, Kang T, Zhao C, Huang Z, Zhang X. Activity of in vitro anti-influenza virus of arctigenin. Zhongcaoyao 2002; 33: 724-6.

41 Swarup V, Ghosh J, Mishra MK, Basu A. Novel strategy for treatment of Japanese encephalitis using arctigenin, a plant lignan. J Antimicrob Chemother 2008; 61: 679-88.

42 Schroder HC, Merz H, Steffen R, Muller WE, Sarin PS, Trumm S, et al. Differential in vitro anti-HIV activity of natural lignans. Z Naturforsch C 1990; 45: 1215-21.

43 Eich E, Pertz H, Kaloga M, Schulz J, Fesen MR, Mazumder A, et al. (-)-Arctigenin as a lead structure for inhibitors of human immunodeficiency virus type-1 integrase. J Med Chem 1996; 39: 86-95.

44 Toyoda T, Tsukamoto T, Mizoshita T, Nishibe S, Deyama T, Takenaka Y, et al. Inhibitory effect of nordihydroguaiaretic acid, a plant lignan, on Helicobacter pylori-associated gastric carcinogenesis in Mongolian gerbils. Cancer Sci 2007; 98: 1689-95.

45 Pereira JV, Bergamo DCB, Pereira JO, Franca SdC, Pietro RCLR, SilvaSousa YTC. Antimicrobial activity of Arctium lappa constituents against microorganisms commonly found in endodontic infections. Braz Dentl J 2005; 16: 192-6.

46 Elsayed A. Aboutabla, El-Tantawyb ME, Shamsb MM. Chemical composition and antimicrobial activity of volatile constituents from the roots, leaves, and seeds of Arctium lappa L (Asteraceae) grown in Egypt. Egypt Pharm J 2013; 12: 173-6.

47 Gentil M, Pereira JV, Sousa YTCS, Pietro R, Neto MDS, Vansan LP, et al. In vitro evaluation of the antibacterial activity of Arctium lappa 
as a phytotherapeutic agent used in intracanal dressings. Phytother Res 2006; 20: 184-6.

48 He J, Zhao Y, Sun X, Wu Q, Pan Y. Antibacterial effects of burdock (Arctium lappa L) concentrate on Vibrio parahemolyticus. Nat Prod Res Dev 2012; 24: 381-4.

49 Gu Y, Sun XX, Ye JM, He L, Yan SS, Zhang HH, et al. Arctigenin alleviates ER stress via activating AMPK. Acta Pharmacol Sin 2012; 33: 941-52.

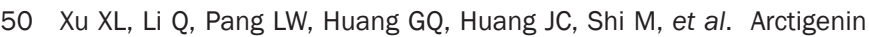
promotes cholesterol efflux from THP-1 macrophages through PPARgamma/LXR-alpha signaling pathway. Biochem Bioph Res Co 2013; 441: 321-6.

51 Sun Y, Zang Z, Zhong L, Wu M, Su Q, Gao X, et al. Identification of adiponectin receptor agonist utilizing a fluorescence polarization based high throughput assay. PLoS One 2013; 8: e63354.

52 Li W, Zhang Z, Zhang K, Xue Z, Li Y, Zhang Z, et al. Arctigenin suppress Th17 cells and ameliorates experimental autoimmune encephalomyelitis through AMPK and PPAR-gamma/ROR-gammat signaling. Mol Neurobiol 2016; 53: 5356-66.

53 Qi Y, Dou DQ, Jiang H, Zhang BB, Qin WY, Kang K, et al. Arctigenin attenuates learning and memory deficits through PI3K/Akt/GSK3beta pathway reducing Tau hyperphosphorylation in abeta-induced AD mice. Planta Med 2017; 83: 51-6.

54 Song J, Li N, Xia Y, Gao Z, Zou SF, Yan YH, et al. Arctigenin confers neuroprotection against mechanical trauma injury in human neuroblastoma SH-SY5Y cells by regulating miRNA-16 and miRNA199a expression to alleviate inflammation. J Mol Neurosci 2016; 60: 115-29.

55 Takasaki M, Konoshima T, Komatsu K, Tokuda H, Nishino H. Antitumor-promoting activity of lignans from the aerial part of Saussurea medusa. Cancer Lett 2000; 158: 53-9.

56 Zeng Y, Yokohira M, Takeuchi H, Saoo K, Yamakawa K, Matsuda $\mathrm{Y}$, et al. Lack of significant modifying effect of arctiin on prostate carcinogenesis in probasin/SV40 T antigen transgenic rats. Cancer Lett 2005; 222: 145-51.

57 Hasumura M, Ueda M, Onose J-i, Imai T, Hirose M. Lack of a significant effect of arctiin on development of 7,12-dimethylbenz(a) anthracene-induced mammary tumors in ovariectomized SpragueDawley rats. Nutr Cancer 2007; 57: 201-8.

58 Kato T, Hirose M, Takahashi S, Hasegawa R, Kohno T, Nishibe S, et al. Effects of the lignan, arctiin, on 17-beta ethinyl estradiol promotion of preneoplastic liver cell foci development in rats. Anticancer Res 1998; 18: 1053-7.

59 Hirose M, Yamaguchi T, Lin C, Kimoto N, Futakuchi M, Kono T, et al. Effects of arctiin on PhIP-induced mammary, colon and pancreatic carcinogenesis in female Sprague-Dawley rats and MelQx-induced hepatocarcinogenesis in male F344 rats. Cancer Lett 2000; 155: 79-88.

60 Zheng Y, Cai S, Xu X, Fu S. Dyuamical studies on metabolic chemistry of lignans from seeds of Arctium lappa. Zhongguo Zhongyao Zazhi 2005; 30: 1287-9.

61 Zhao YF, Song FR, Zhao LP, Liu SY. Studies on the biotransformation of arctigenin using electrospray ionization mass spectrometry. Acta Chim Sinica 2009; 67: 1123-6.

62 Jin JS, Hattori M. Human intestinal bacterium, strain END-2 is responsible for demethylation as well as lactonization during plant lignan metabolism. Biol Pharm Bull 2010; 33: 1443-7.

63 Xie L, Ahn E, Akao T, Abdel-Hafez AA, Nakamura N, Hattori M. Transformation of arctiin to estrogenic and antiestrogenic substances by human intestinal bacteria. Chem Pharm Bull 2003; 51: 378-84.

64 Nose M, Fujimoto T, Takeda T, Nishibe S, Ogihara Y. Structural transformation of lignan compounds in rat gastrointestinal-tract. Planta Med 1992; 58: 520-3.

65 Heinonen S, Nurmi T, Liukkonen K, Poutanen K, Wahala K, Deyama $\mathrm{T}$, et al. In vitro metabolism of plant lignans: new precursors of mammalian lignans enterolactone and enterodiol. J Agric Food Chem 2001; 49: 3178-86.

66 Wang W, Pan Q, Han XY, Wang J, Tan RQ, He F, et al. Simultaneous determination of arctiin and its metabolites in rat urine and feces by HPLC. Fitoterapia 2013; 86: 6-12.

67 Zeng XY, Dong S, He NN, Jiang CJ, Dai Y, Xia YF. Comparative pharmacokinetics of arctigenin in normal and type 2 diabetic rats after oral and intravenous administration. Fitoterapia 2015; 105: 119-26.

68 Gao Q, Zhang Y, Wo S, Zuo Z. Extensive intestinal first-pass metabolism of arctigenin: evidenced by simultaneous monitoring of both parent drug and its major metabolites. J Pharm Biomed Anal 2014; 91: 60-7.

69 Li J, Li X, Ren YS, Lv YY, Zhang JS, Xu XL, et al. Elucidation of arctigenin pharmacokinetics and tissue distribution after intravenous, oral, hypodermic and sublingual administration in rats and beagle dogs: integration of in vitro and in vivo findings. Front Pharmacol 2017; 8: 376.

70 He F, Dou DQ, Hou Q, Sun Y, Kang TG. Pharmacokinetic study of arctigenin in rat plasma and organ tissue by RP-HPLC method. Nat Prod Res 2013; 27: 903-6.

71 Jin J, Zhao Y, Nakamura N, Akao T, Kakiuchi N, Hattori M. Isolation and characterization of a human intestinal bacterium, Eubacterium sp. ARC-2, capable of demethylating arctigenin, in the essential metabolic process to enterolactone. Biol Pharm Bull 2007; 30: 904-11.

72 Gao Q, Zhang Y, Wo S, Zuo Z. Elucidation of arctigenin pharmacokinetics after intravenous and oral administrations in rats: integration of in vitro and in vivo findings via semi-mechanistic pharmacokinetic modeling. AAPS J 2014; 16: 1321-33.

73 Gao Q, Zhang Y, Wo S, Zuo Z. Hydrolysis is the dominating in vivo metabolism pathway for arctigenin: identification of novel metabolites of arctigenin by LC/MS/MS after oral administration in rats. Planta Med 2013; 79: 471-9.

74 Xin H, Xia YL, Hou J, Wang P, He W, Yang L, et al. Identification and characterization of human UDP-glucuronosyltransferases responsible for the in-vitro glucuronidation of arctigenin. J Pharm Pharmacol 2015; 67: 1673-81.

75 Ikeda M, Sato A, Mochizuki N, Toyosaki K, Miyoshi C, Fujioka R, et al. Phase I trial of GBS-01 for advanced pancreatic cancer refractory to gemcitabine. Cancer Sci 2016; 107: 1818-24.

76 Zhang S, Wang N. Deterimination of the content of arctiin in yinqiaojiedu granules by HPLC. Shanxi Zhongyi Zazhi 2012; 33: 229-30.

77 Sun G, Yanling S, Li Y, Liang J. Quantitative determination of Yinqiao Jiedu pill reference fingerprint criteria by 3 wavelength quantified fingerprints coupled with 4 compounds analysis. Zhongnan Yaoxue 2013; 11: 366-71.

78 Ouyang J, Kang L, Hu W. Determination of forsythin and arctiin in vitamin C Yinqiao tablets by HPLC. Zhongguo Yaoshi 2008; 22 : 692-4.

79 Yang Q, Zhang J, Li J. Determination of forsythin and arctiin in lingyangganmao tablets by HPLC. Zhongchengyao 2007; 29: 383-5.

$80 \mathrm{Li} \mathrm{D}$. Simultaneous detection of forsythin and arctiin in lingyangganmao tables by HPLC. Shoudu Yiyao 2008; 1: 51-2.

81 Zhou X, Jin F, Li T, Sha M, Meng X, Cao A. Determination of arctiin in fengre ganmao granule s by HPLC. Yaoxue Jinbu 2004; 28: 327-9.

82 Shi C, Tu L, Cao Y. Determination of arctiin in fengreganmao granules 
by HPLC. Yunnan Daxue Xuebao 2009; 31: 456-8.

83 Jadad AR, Moore RA, Carroll D, Jenkinson C, Reynolds DJ, Gavaghan DJ, et al. Assessing the quality of reports of randomized clinical trials: is blinding necessary? Control Clin Trials 1996; 17: 1-12.

84 Ma S, Liu D, Niu R, Liu R, Ji Q, Zhan J, et al. Double-blind, randomized, placebo-controlled multi-center phase III clinical trial of Arctiin granule in the treatment of diabetic nephropathy. Zhongguo Linchuang Yaolixue Zazhi 2011; 27: 15-8.

85 Ma S, Liu D, Niu R, Liu R, Ji Q, Zhan J, et al. Tangjiangshenkang granule in treatment of diabetic nephropathy:a doubleblind, randomized, placebo-controlled multicentre clinical trial. Zhongguo Xinyao yu Linchuang Zazhi 2011; 30: 16-9.

86 Zhang L, Li P, Zhang X, Wu J, Bao M. Clinical observation on treatment of diabetic nephropathy with fructus arctii powders. Sichuan Yixue 2011; 32: 656-8.

87 Lee DH, Seo ES, Hong JT, Lee GT, You YK, Lee KK, et al. The efficacy and safety of a proposed herbal moisturising cream for dry skin and itch relief: a randomised, double-blind, placebo-controlled trial-study protocol. BMC Complement Altern Med 2013; 13: 330.

88 Miglani A, Manchanda R. Observational study of Arctium lappa in the treatment of acne vulgaris. Homeopathy 2014; 103: 203-7.

89 Dall'acqua S, Tome F, Vitalini S, Agradi E, Innocenti G. In vitro estrogenic activity of Asplenium trichomanes $L$ extracts and isolated compounds. J Ethnopharmacol 2009; 122: 424-9.

90 Liu S, Chen K, Schliemann W, Strack D. Isolation and identification of arctiin and arctigenin in leaves of burdock (Arctium lappa $L$ ) by polyamide column chromatography in combination with HPLC-ESI/ MS. Phytochem Anal 2005; 16: 86-9.

91 Predes FS, Ruiz ALTG, Carvalho JE, Foglio MA, Dolder H. Antioxidative and in vitro antiproliferative activity of Arctium lappa root extracts. BMC Complement Altern Med 2011; 11: 25.

92 Hausott B, Greger H, Marian B. Naturally occurring lignans efficiently induce apoptosis in colorectal tumor cells. J Cancer Res Clin Oncol 2003; 129: 569-76.

93 Chan YS, Cheng LN, Wu JH, Chan E, Kwan YW, Lee SMY, et al. A review of the pharmacological effects of Arctium lappa (burdock). Inflammopharmacology 2011; 19: 245-54.

$94 \mathrm{Ge} \mathrm{L}$, Zhang H, Tian S. Content determination of arctiin and arctigen from different parts of Arctium tomentosum by RP-HPLC. Zhongguo Shiyan Fangjixue Zazhi 2010; 16: 41-3.

95 Tundis R, Statti G, Menichini F, Delle Monache F. Arctiin and onopordopicrin from Carduus micropterus ssp perspinosus. Fitoterapia 2000; 71: 600-1.

96 Janackovic P, Tesevic V, Milosavljevic S, Vajs V, Marin PD. Sesquiterpene lactones, lignans and flavones of Centaurea affinis. Biochem Syst Ecol 2004; 32: 355-7.

97 Shoeb M, Macmanus SM, Kumarasamy Y, Jaspars M, Nahar L, ThooLin PK, et al. Americanin, a bioactive dibenzylbutyrolactone lignan, from the seeds of Centaurea americana. Phytochemistry 2006; 67: 2370-5.

98 Csapi B, Hajdu Z, Zupko I, Berenyi A, Forgo P, Szabo P, et al. Bioactivity-guided isolation of antiproliferative compounds from Centaurea arenaria. Phytother Res 2010; 24: 1664-9.

99 Aslan Ü, Öksüz S. Chemical constituents of Centaurea cuneifolia. Turk J Chem 1999; 23: 15-20.

100 Szokol-Borsodi L, Solyomvary A, Molnar-Perl I, Boldizsar I. Optimum yields of dibenzylbutyrolactone-type lignans from Cynareae fruits, during their ripening, germination and enzymatic hydrolysis processes, determined by on-line chromatographic methods. Phytochem Anal 2012; 23: 598-603.

101 Shoeb M, Rahman MM, Nahar L, Delazar A, Jaspars M, Macmanus
SM. Bioactive lignans from the seeds of Centaurea macrocephala. DARU J Pharm Sci 2004; 12: 87-93.

102 Middleton M, Cox PJ, Jaspars M, Kumarasamy Y, Nahar L, Reid R, et al. Dibenzylbutyrolactone lignans and indole alkaloids from the seeds of Centaurea nigra (Asteraceae). Biochem Syst Ecol 2003; 31: 653-6.

103 Christensen LP. Flavones and other constituents from Centaurea species. Phytochemistry 1991; 30: 2663-5.

104 Çelik S, Rosselli S, Maggio AM, Raccuglia RA, Uysal I, Kisiel W, et al. Guaianolides and lignans from the aerial parts of Centaurea ptosimopappa. Biochem Syst Ecol 2006; 34: 349-52.

105 Youssef D, Frahm AW. Constituents of the Egyptian Centaurea scoparia; III. Phenolic constituents of the aerial parts. Planta Med 1995; 61: 570-3.

106 Bruno M, Diaz JG, Herz W. Guaianolides and lignans from Centaurea solstitialis subs schouwii. Phytochemistry 1991; 30: 4165-6.

107 Fortuna AM, De Riscala EC, Catalan CA, Gedris TE, Herz W. Sesquiterpene lactones from Centaurea tweediei. Biochem Syst Ecol 2001; 29: 967-71.

108 Boldizsar I, Kraszni M, Toth F, Noszal B, Molnar-Perl I. Complementary fragmentation pattern analysis by gas chromatography-mass spectrometry and liquid chromatography tandem mass spectrometry confirmed the precious lignan content of Cirsium weeds. J Chromatogr A 2010; 1217: 6281-9.

109 Fan CQ, Zhu XZ, Zhan ZJ, Ji XQ, Li H, Yue JM. Lignans from Saussurea conica and their NO production suppressing activity. Planta Med 2006; 72: 590-5.

110 Yoo JH, Lee HJ, Kang K, Jho EH, Kim CY, Baturen D, et al. Lignans inhibit cell growth via regulation of Wnt/beta-catenin signaling. Food Chem Toxicol 2010; 48: 2247-52.

111 Kang K, Lee HJ, Kim CY, Lee SB, Tunsag J, Batsuren D, et al. The chemopreventive effects of Saussurea salicifolia through induction of apoptosis and phase II detoxification enzyme. Biol Pharm Bull 2007; 30: 2352-9.

112 Lin HR. Sesquiterpene lactones from Tithonia diversifolia act as peroxisome proliferator-activated receptor agonists. Bioorg Med Chem Lett 2012; 22: 2954-8.

113 Formisano C, Rigano D, Russo A, Cardile V, Caggia S, Apostolides Arnold N, et al. Phytochemical profile and apoptotic activity of Onopordum cynarocephalum. Planta Med 2012; 78: 1651-60.

114 Lazari D, Garcia B, Skaltsa H, Pedro JR, Harvala C. Sesquiterpene lactones from Onopordon Iaconicum and O-sibthorpianum. Phytochemistry 1998; 47: 415-22.

115 Attoumbre J, Bienaime C, Dubois F, Fliniaux MA, Chabbert B, BaltoraRosset S. Development of antibodies against secoisolariciresinolapplication to the immunolocalization of lignans in Linum usitatissimum seeds. Phytochemistry 2010; 71: 1979-87.

116 Tokar M, Klimek B. The content of lignan glycosides in Forsythia flowers and leaves. Acta Pol Pharm 2004; 61: 273-8.

117 Lee JH, Lee JY, Kim TD, Kim CJ. Antiasthmatic action of dibenzylbutyrolactone lignans from fruits of Forsythia viridissima on asthmatic responses to ovalbumin challenge in conscious guineapigs. Phytother Res 2011; 25: 387-95.

$118 \mathrm{Kim}$ M, Moon HT, Lee DG, Woo E. A new lignan glycoside from the stem bark of Styrax japonica S et Z. Arch Pharm Res 2007; 30: 425-30.

119 Jang YP, Kim SR, Kim YC. Neuroprotective dibenzylbutyrolactone lignans of Torreya nucifera. Planta Med 2001; 67: 470-2.

120 Zhao Y, Nookandeh A, Schneider B, Sun XF, Schmitt B, Stockigt J. Lignans from Torreya jackii identified by stopped-flow highperformance liquid chromatography nuclear magnetic resonance 
spectroscopy. J Chromatogr A 1999; 837: 83-91.

121 Sun L, Liu L, Yang W, Zhao T, Tong L. Simultaneous determination of matairesinol and arctigenin in the Wikstroemia indica (Linn) C A Mey by HPLC. Shenyang Yaoke Daxue Xuebao 2010; 27: 893-7.

122 Li A, Wang J, Zhu D, Zhang X, Pan R, Wang R. Arctigenin suppresses transforming growth factor-beta1-induced expression of monocyte chemoattractant protein-1 and the subsequent epithelialmesenchymal transition through reactive oxygen species-dependent ERK/NF-kappaB signaling pathway in renal tubular epithelial cells. Free Radic Res 2015; 49: 1095-113.

123 Wu X, Dou Y, Yang Y, Bian D, Luo J, Tong B, et al. Arctigenin exerts anti-colitis efficacy through inhibiting the differentiation of Th1 and Th17 cells via an mTORC1-dependent pathway. Biochem Pharmacol 2015; 96: 323-36.

124 Chen J, Li W, Jin E, He Q, Yan W, Yang H, et al. The antiviral activity of arctigenin in traditional Chinese medicine on porcine circovirus type 2 . Res Vet Sci 2016; 106: 159-64.

125 Kasper R, Gansser D, Doehmer J. Biotransformation of the naturallyoccurring lignan (-)-arctigenin in mammalian-cell lines geneticallyengineered for expression of single cytochrome-P450 isoforms. Planta Med 1994; 60: 441-4.

126 Nose M, Fujimoto T, Nishibe S, Ogihara Y. Structural transformation of lignan compounds in rat gastrointestinal-tract; II. Serum concentration of lignans and their metabolites. Planta Med 1993; 59: 131-4.

127 Zou Q, Gu Y, Lu R, Zhang T, Zhao GR, Liu C, et al. Development of an LC/MS/MS method in order to determine arctigenin in rat plasma: its application to a pharmacokinetic study. Biomed Chromatogr 2013; 27: 1123-8. 